\title{
Fertilization capacity with rainbow trout DNA-damaged sperm and embryo developmental success
}

\author{
S Pérez-Cerezales, S Martínez-Páramo', J Beirão and M P Herráez \\ Department of Molecular Biology, Area of Cell Biology, University of León, 24071 León, Spain and ${ }^{1}$ Center for Marine \\ Science-CCMAR, University of Algarve, 8005-139 Faro, Portugal \\ Correspondence should be addressed to M P Herráez; Email: paz.herraez@unileon.es
}

\begin{abstract}
Mammalian spermatozoa undergo a strong selection process along the female tract to guarantee fertilization by good quality cells, but risks of fertilization with DNA-damaged spermatozoa have been reported. In contrast, most external fertilizers such as fish seem to have weaker selection procedures. This fact, together with their high prolificacy and external embryo development, indicates that fish could be useful for the study of the effects of sperm DNA damage on embryo development. We cryopreserved sperm from rainbow trout using egg yolk and low-density lipoprotein as additives to promote different rates of DNA damage. DNA fragmentation and oxidization were analyzed using comet assay with and without digestion with restriction enzymes, and fertilization trials were performed. Some embryo batches were treated with 3-aminobenzamide (3AB) to inhibit DNA repair by the poly (ADP-ribose) polymerase, which is an enzyme of the base excision repair pathway. Results showed that all the spermatozoa cryopreserved with egg yolk carried more than $10 \%$ fragmented DNA, maintaining fertilization rates of $61.1 \pm 2.3$ but a high rate of abortions, especially during gastrulation, and only $14.5 \pm 4.4$ hatching success. Furthermore, after $3 \mathrm{AB}$ treatment, hatching dropped to $3.2 \pm 2.2$, showing that at least $10 \%$ DNA fragmentation was repaired. We conclude that trout sperm maintains its ability to fertilize in spite of having DNA damage, but that embryo survival is affected. Damage is partially repaired by the oocyte during the first cleavage. Important advantages of using rainbow trout for the study of processes related to DNA damage and repair during development have been reported.

Reproduction (2010) 139 989-997
\end{abstract}

\section{Introduction}

In recent years, sperm DNA damage assessment has gained special attention as an important sperm quality marker, linked with sperm fitness as well as with offspring quality. In this sense, some techniques to quantify sperm DNA integrity (sperm chromatin structure assay (SCSA), TUNEL, acridine orange test, Halomax, single cell gel electrophoresis (SCGE; comet assay), etc.) have been developed and applied to several species from different phyla (Singh et al. 1988, Evenson et al. 1991, Sun et al. 1997, Lee \& Steinert 2003, Maluszynska \& Juchimiuk 2005, Enciso et al. 2006, Andrabi 2007). Most of the reported data indicate that DNA damage is correlated with a reduction in fertilization ability, with development failure after fertilization and offspring problems (Kopeika et al. 2004, Evenson \& Wixon 2006, Fernandez-Gonzalez et al. 2008, Barroso et al. 2009, Schulte et al. 2010). DNA damage could be caused in spermatozoa by many different factors, from sperm aging to the effect of toxic agents, freezing process, X-ray irradiation, etc. (Tarin et al. 2000, Andrabi 2007, Pérez-Cerezales et al. 2009, Thomson et al. 2009). Some of these factors are also associated with other kinds of injuries which are directly related to fertilization failure, such as membrane damage, immobility, and mitochondrial membrane depolarization (Ahmadi \& Ng 1999, Irvine et al. 2000, Holt \& Van Look 2004). In mammals, it has been suggested that the strong selective process undergone by sperm in the female tract (by elimination of defective spermatozoa, sperm competition, cryptic female choice, etc.) is probably unrelated to a DNA-scanning mechanism, and that some kind of link between sperm phenotype and genotype could be involved in this process (Holt \& Van Look 2004, Khalil et al. 2006, Satake et al. 2006, Suarez \& Pacey 2006, Rodriguez-Martinez 2007). Hourcade et al. (2010) showed that selection of DNA-undamaged spermatozoa occurs in mice during the transit through the oviduct as well as during the contact with the vitelline membrane, but this selective process is dependent on the source of sperm damage and probably related to the presence of damage in other cell structures. Sperm selection among mammals must be rigorous because a lot of time and energy is spent in obtaining a reduced number of embryos, which require an additional effort to develop properly. Taking into account that DNA damage can be promoted in different ways that do not necessarily correlate with changes in structures/molecules related 
to survival in the female tract or with fertilization ability, the evaluation of the effects of fertilization with DNA-damaged spermatozoa on offspring development deserves more attention. The use of some assisted reproductive technologies (ARTs) for human reproduction and animal breeding facilitates fertilization success, avoiding the selection process that takes place in the female tract and during the interaction with the vitelline membrane in such a way that spermatozoa excluded during natural fertilization would be able to penetrate the oocyte and initiate development (Ahmadi \& Ng 1999, Fernandez-Gonzalez et al. 2008, Zini \& Sigman 2009). Studies performed with DNA-damaged human and mouse sperm demonstrated their fertilization ability in zona-free hamster oocytes (Ahmadi \& Ng 1999) or via ICSI (Fernandez-Gonzalez et al. 2008), but a high degree of developmental failure, altered karyotypes, modified phenotypes, and even histopathological events were detected in embryos and newborn mice. Previous reports also suggest an excess of major and minor birth defects, low birth weight, and frequency of some imprinting-related syndromes in ART children, especially with the use of ICSI (Bowdin et al. 2007, Lim et al. 2009). These data reflect the importance of studying the consequences of fertilizing with DNA-modified sperm. DNA strand breaks and base oxidization are promoted during freezing-thawing, as has been described in several species (Baumber et al. 2003, Pérez-Cerezales et al. 2009, Thomson et al. 2009, Yamauchi et al. 2009). Thus, the use of cryopreserved sperm combined with other ARTs could increase the risk of undesirable modified genetic material being transmitted to the offspring. The analysis of the impact of fertilization with damaged pronuclei on the progeny is limited in mammals by the low number of embryos obtained per mating and the internal development of the embryo, which makes the progressive evaluation of development as well as the study of DNA repair mechanisms difficult. DNA damage such as simple or double strand breaks, base modifications, base mismatch, etc. could be repaired by the oocyte after fertilization, but there is not enough information about the extent of insults which can be repaired in the zygote or even about the eventual modifications in the DNA induced by the repairing mechanisms themselves. Deeper studies are required in this regard in order to assess the real impact of fertilizing with an injured genome in the future offspring. DNA-repairing pathways are highly conserved mechanisms, and the expression of different enzymes involved in the process has been detected during early development in different species from fish to mammals (Matsuda \& Tobari 1989, Hales et al. 2005, Marchetti et al. 2007, Fortier et al. 2009).

In external fertilizers, such as fish, sperm selection mechanisms before fertilization are different, and much simpler. Energy is not spent on offspring care, many embryos are produced and only a percentage of the embryos survive, so selective pressure undergone by spermatozoa is lower than that undergone by spermatozoa in mammals. In fish, spermatozoa are delivered into water, an aggressive environment which activates the motility, and fertilization lasts no longer than some seconds or minutes after ejaculation when ATP stores are exhausted (Jalabert 2005, Cabrita et al. 2008, Cosson et al. 2008). So, natural selection is focused on fast fertilization with a simple spermatozoa structure and relatively simple strategies to ensure fertilization (increased ejaculate density, high spermatozoa velocity, chemotaxis, etc.; Holt \& Van Look 2004, Cosson et al. 2008). In this case, spermatozoa selection and cryptic female choice could be less significant than in internal fertilizers, and fertilization may be a matter of certain probability (Holt \& Van Look 2004). This suggests that natural fertilization with DNA-damaged spermatozoa could be more likely in fish than in mammals. Fish could be a very interesting model in this field if a weak selection process allowing natural fertilization with DNA-damaged spermatozoa were confirmed. The ease with which many fish species breed, external embryo development allowing embryo assessment and manipulation throughout development, and high prolificacy, allowing the generation of thousands of embryos per mating, are undoubtedly advantages.

The objective of this study was to check the suitability of rainbow trout as a model for the study of the effects of fertilization with spermatozoa containing damaged DNA promoted by cryopreservation, and evaluate the role of DNA damage in fertilization ability and embryo survival during development as well as analyze the activity of the base excision repair (BER) pathway through the inhibition of the poly (ADP-ribose) polymerase (PARP).

\section{Results \\ Sperm evaluation}

As shown in Table 1, fresh sperm viability (plasma membrane integrity) was $98.66 \% \pm 0.39$, and a high percentage of damaged DNA $(31.99 \% \pm 1.19$ tail DNA) was detected with a basal level of intracellular reactive oxygen species (ROS) of $2.35 \pm 0.07$ median fluorescent intensity (MFI). In the cryopreserved sperm, we detected a significant decrease in viability, with the use of egg yolk as cryoprotectant providing the lowest value $(13.69 \% \pm 0.77$ viable cells). DNA fragmentation also increased after freezing-thawing, especially with the use of egg yolk ( $56.91 \% \pm 1.02$ tail DNA). The ROS content was higher in cryopreserved sperm than in fresh sperm (3.21 \pm 0.14 in sperm frozen with egg yolk and 3.11 \pm 0.13 with its low-density lipoprotein (LDL) fraction). When comet assay was combined with the use of restriction enzymes (endonuclease III (EndIII) and 
Table 1 Sperm parameters in fresh and frozen sperm from rainbow trout (Oncorhynchus mykiss). Cell viability (\%), percentage of tail DNA, and reactive oxygen species (ROS) level for fresh sperm, sperm cryopreserved with $10 \%$ egg yolk or $12 \%$ low-density lipoproteins (LDL), and sperm incubated with $500 \mathrm{mM} \mathrm{H}_{2} \mathrm{O}_{2}$ as positive control for oxidization. For viability and ROS, $10^{4}$ cells were acquired in duplicate per each male and treatment. One hundred cells per male and treatment were analyzed in comet assay. Values are expressed as mean \pm S.E.M.

\begin{tabular}{lccc}
\hline & Viability & $\begin{array}{c}\text { Percentage of } \\
\text { tail DNA }\end{array}$ & ROS \\
\hline Fresh & $98.66 \pm 0.39^{\mathrm{a}}$ & $31.99 \pm 1.19^{\mathrm{a}}$ & $2.35 \pm 0.07^{\mathrm{a}}$ \\
Egg yolk & $13.69 \pm 0.77^{\mathrm{b}}$ & $56.91 \pm 1.02^{\mathrm{b}}$ & $3.21 \pm 0.14^{\mathrm{b}}$ \\
$\mathrm{LDL}$ & $37.55 \pm 1.35^{\mathrm{c}}$ & $49.21 \pm 1.14^{\mathrm{c}}$ & $3.11 \pm 0.13^{\mathrm{b}}$ \\
$\mathrm{H}_{2} \mathrm{O}_{2}$ & & $77.36 \pm 0.96^{\mathrm{d}}$ & $3.74 \pm 0.07^{\mathrm{c}}$ \\
\hline
\end{tabular}

Different letters in the same column indicate significant differences $(P<0.05)$

formamidopyrimidine DNA glycosylase (Fpg)), DNA was cut into oxidized cytosines and guanosines respectively, allowing the detection of oxidized bases (Fig. 1) through an increase in DNA fragmentation. Our results showed an increase in mean DNA fragmentation after digestion with Fpg in fresh sperm but not in cryopreserved samples, indicating a basal level of oxidized guanosines in non-fragmented positions of the strands before cryopreservation.

The distribution of frequencies of DNA damage (Fig. 2) revealed that fragmentation in fresh sperm ranged from 0 to $80 \%$, and over $10 \%$ of the cells displayed a level of damage lower than $10 \%$. After cryopreservation, frequency distribution changed, reducing the number of cells in the lower ranges and increasing the cells in the higher ones. In samples frozen with egg yolk, DNA damage ranged from 10 to $90 \%$, and no undamaged cells were detected

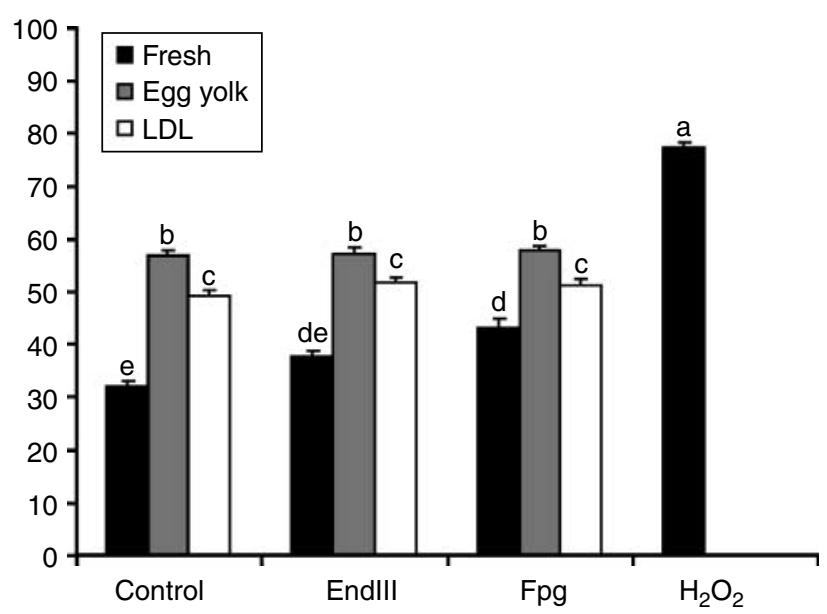

Figure 1 Percentage of tail DNA obtained by SCGE combined with the use of restriction enzymes (EndIII and Fpg from E. coli) for fresh sperm, sperm cryopreserved with egg yolk and $12 \% \mathrm{LDL}$, and samples treated with $500 \mathrm{mM} \mathrm{H}_{2} \mathrm{O}_{2}$ before the comet assay (800 cells per treatment). Bars indicate mean \pm s.E.M. Different letters indicate significant differences $(P<0.05)$. (range from 0 to $10 \%$ ). Sperm cryopreserved with LDL showed a range of damage from 0 to $90 \%$, with only $3 \%$ of cells showing damage in the $0-10 \%$ range.

By combining comet assay with enzymatic digestion (Fig. 2), we observed a reduction of cells with a low level of tail DNA (range from 0 to $20 \%$ and from 0 to 30 for EndIII and Fpg respectively) in fresh sperm, indicating the presence of both oxidized guanosines and cytosines in non-fragmented positions of the strands, and also observed an increase in the number of cells with damage in the higher ranges $(30-40,60-70$, and $60-80 \%$ for EndIII and Fpg respectively). Furthermore, cryopreservation with egg yolk also promoted an increase in the number of cells within the higher ranges (50-60\%) of tail DNA, and a decrease in lower values (40-50\%) when Fpg was used, but no effect was detected for EndIII, indicating the presence of oxidized guanosines but not of cytosines. LDL promoted a significant increase in the number of cells with a high level of tail DNA when endonucleases were used $(70-80 \%$ for EndIII and $40-50 \%$ for Fpg) and a decrease for lower ones (0-10 and 30-40\% for Fpg), implying the presence of both oxidized bases.

\section{Fertilization rates and embryo development}

Fresh sperm showed higher fertilization (90.6 \pm 2.46$)$ and hatching rates (78.3 \pm 5.4 ) than frozen sperm (Fig. 3). Furthermore, the use of egg yolk promoted lower fertilization $(61.1 \pm 2.3)$ and hatching rates $(14.5 \pm 4.4)$ than that of $\operatorname{LDL}(66.7 \pm 2.1$ and $38 \pm 5.4$ respectively). When eggs fertilized with fresh and LDL-cryopreserved sperm were incubated with 3 -aminobenzamide (3AB), no differences were found in relation to non-treated ones in terms of fertilization and hatching rates. Nevertheless, the $3 \mathrm{AB}$ treatment promoted a decrease in hatching rates in batches of cryopreserved sperm fertilized with egg yolk (3.2 \pm 2.2$)$. As shown in Fig. 4, the percentage of abortions increased during development in embryos obtained from eggs fertilized with cryopreserved sperm, showing that most abortions were promoted in the transition from epibolia to somite stage (48.13 and $44.62 \%$ of the abortions with egg yolk and LDL respectively). This transition was also the most sensitive to the $3 \mathrm{AB}$ treatment in embryos obtained with egg yolkcryopreserved sperm (58.21\% of the abortions).

\section{Discussion}

It is suspected that, in mammals, DNA-damaged spermatozoa are impaired to fertilize under natural conditions by the high selective pressure occurring in the female tract and during sperm-egg recognition (Holt \& Van Look 2004, Khalil et al. 2006, Satake et al. 2006, Suarez \& Pacey 2006, Rodriguez-Martinez 2007, Yeates et al. 2009). These selection mechanisms are related to sperm structures that could also be modified in spermatozoa carrying damaged DNA 

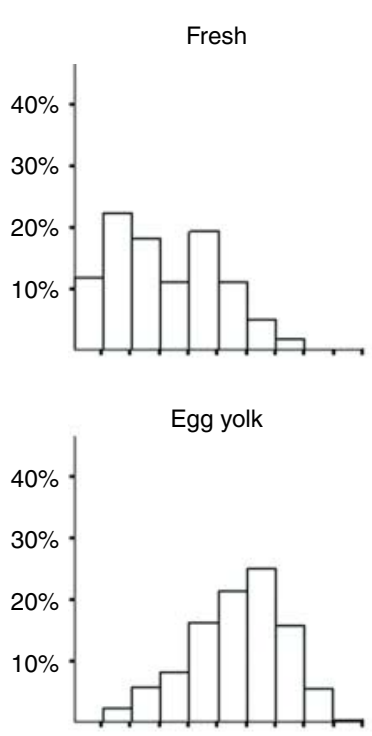

LDL
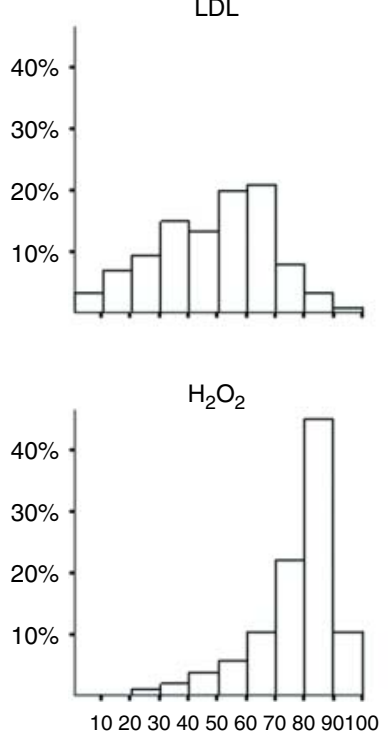

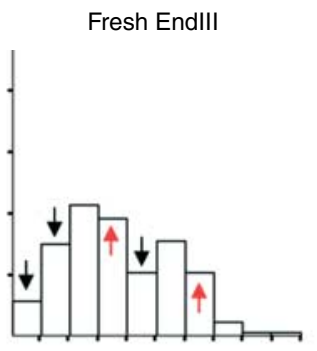

Egg yolk EndIII

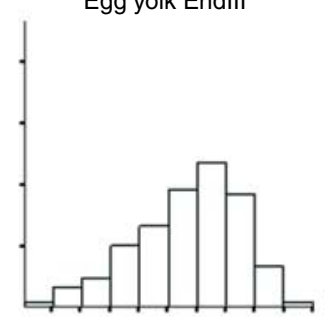

LDL EndIII

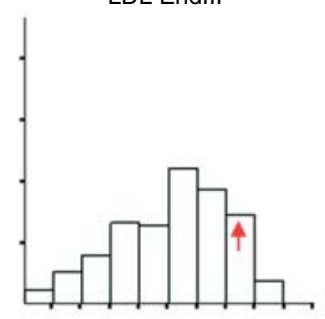

Fresh Fpg

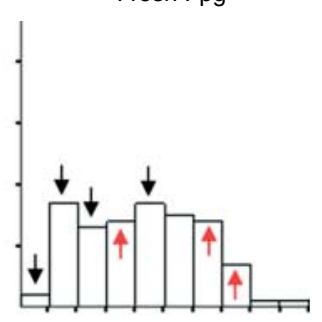

Egg yolk Fpg

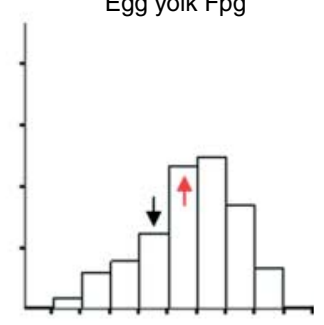

LDL Fpg

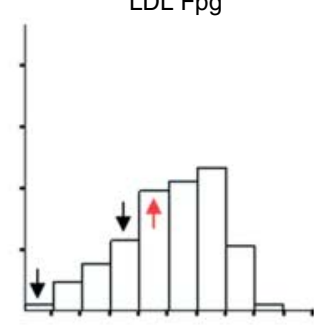

(Tarin et al. 2000, Andrabi 2007, Thomson et al. 2009). The use of ARTs could be bypassing the natural mechanisms selecting the spermatozoa competent to fertilize, allowing DNA-damaged sperm to reach and enter the egg with unknown consequences for the offspring (Zini \& Sigman 2009). This effect could be magnified when ARTs are combined with sperm cryopreservation that promotes the production of DNA damage in spermatozoa. Previous works point to a lower selection pressure in external fertilizers, in which the encounter with eggs is suspected to be more a matter of probability, mainly depending on the presence of numerous spermatozoa close to the egg and on a superior ability to withstand the hyposmotic stress when released in water (Holt \& Van Look 2004). This could facilitate the experimental application of fertilization processes with injured spermatozoa in order to analyze the effects of sperm DNA damage after fertilization, its role during development, and the mechanisms to repair this damage by the oocyte. With this goal in mind, we decided to perform the study with rainbow trout, a species whose reproductive biology is well known, and which is easy to breed in captivity and very prolific.

In our study, we tested two cryopreservation procedures that promoted different degrees of sperm damage. When DNA fragmentation and membrane integrity were analyzed in fresh sperm, we found an apparently good status of plasma membrane and a high level of DNA fragmentation, $31.99 \% \pm 1.19$, in comparison with other studies in the same species, reporting from 6 to 20\% (Cabrita et al. 2005, Dietrich et al. 2005, Pérez-Cerezales et al. 2009), with some of them using the same protocol. This could be related to semen 


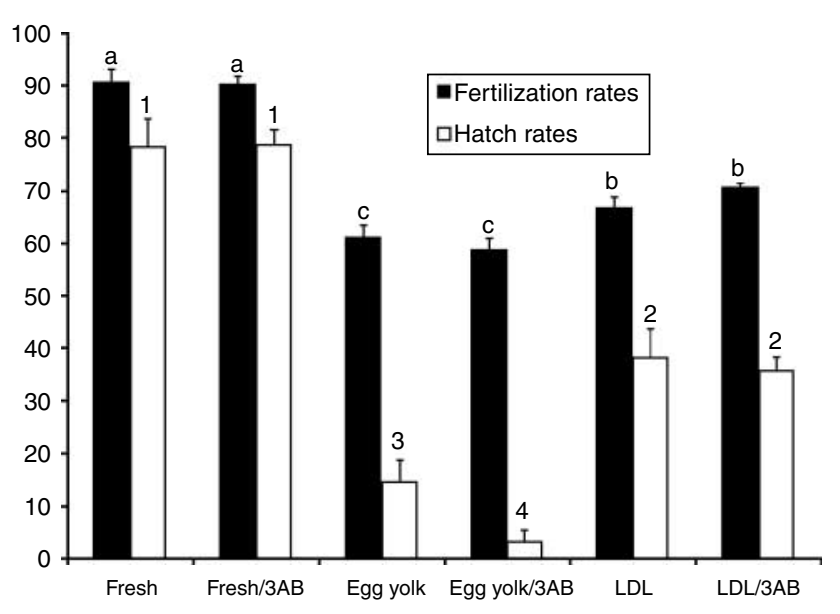

Figure 3 Fertilization and hatching rates after egg fertilization with fresh sperm and sperm cryopreserved with egg yolk and $12 \%$ LDL at hatching. $3 A B$ indicates eggs treated with 3 -aminobenzamide ( $3 A B)$ after fertilization during the first cleavage (8 batches per treatment, 200 eggs per batch). Bars indicate mean \pm s.E.M. Different letters or numbers indicate significant differences $(P<0.05)$.

collection at the end of the optimal moment of the reproductive season when some sperm aging events appear, initially affecting DNA integrity but not membrane integrity, or fertilization capacity, as was described by Pérez-Cerezales et al. (2010) who compared the quality and freezability of the sperm collected during the reproductive season. Sampling was performed at this time, because a higher susceptibility to cryodamage was expected and this was considered beneficial for the objectives of the present work. Performance of the alkaline lyses at a $\mathrm{pH}$ of 12 allowed the identification of single and double strand breaks (Lee \& Steinert 2003), with it being a more sensitive method than the application of TUNEL or comet assay at a neutral $\mathrm{pH}$, which only reveals double strand breaks. This method is considered to detect the actual genotoxic effects of any treatment (Liao et al. 2009).

The analyzed parameters revealed that after freezingthawing, considerable damage was produced. With the use of egg yolk as cryoprotectant, plasma membrane and DNA suffer a higher level of damage than with the use of LDL as was described previously in different species (Moussa et al. 2002, Hu et al. 2008, Yamauchi et al. 2009, Pérez-Cerezales et al. 2010). As was suggested by Pérez-Cerezales et al. (2010), protection of both additives is primarily directed to plasma membrane, which indirectly protects DNA. The LDL fraction of egg yolk concentrates the protective molecules, eliminating some others that could have an antagonist effect on pure egg yolk. The use of the two protectants provided samples with different levels of DNA fragmentation for further fertilization trials. The generation of ROS is considered as one of the main causes of cryodamage, especially in DNA injury, and antioxidant agents are commonly included in the extenders (Baumber et al. 2003, Li et al. 2007, Thomson et al. 2009). Our results showed an increase in ROS production after cryopreservation, which was similar to the levels detected with both the tested cryoprotectants. Positive control incubated with $\mathrm{H}_{2} \mathrm{O}_{2}$ promoted significantly higher levels of radicals. To show the direct effect of oxidization on DNA molecules, we combined the use of EndIII and Fpg digestion with the comet assay showing the presence of oxidized bases in both fresh and cryopreserved samples located in the non-fragmented positions of the DNA strands. The presence of oxidized bases in fresh sperm could be related to the presence of senescent cells, and could affect DNA sensitivity to cryopreservation as it has been described that oxidized bases could transform directly into DNA breakages increasing fragmentation during freezing-thawing (Box et al. 2001, Thomson et al. 2009). A higher level of post-thaw DNA strand breaking was effectively detected. Our results also suggest that guanosines are more prone than cytosines to be oxidized during freezing-thawing, as has been reported by other authors (Box et al. 2001). On the other hand, not all base oxidizations promote DNA strand breaks, because further digestion with specific endonucleases increased fragmentation rates. The presence of oxidized bases is not detected when DNA integrity is evaluated using the comet assay without digestion or other methods such as TUNEL and SCSA, and could have implications during embryo development.

It is important to highlight that sperm cryopreserved with egg yolk maintained $13 \%$ of cells with intact membrane integrity (and fertilizing spermatozoa should belong to this category), which produced levels of DNA damage higher than $10 \%$ of fragmented DNA in all the spermatozoids, plus additional oxidized guanosines. This fact implies that every embryo produced from



Figure 4 Cumulative percentage of abortions during development at different stages (epibolia, somite, eyed, and hatch) with or without $3 \mathrm{AB}$ incubation during the first cleavage ( 8 batches per treatment, 200 eggs per batch). Lines indicate mean \pm S.E.M. Different letters indicate significant differences between treatments $(P<0.05)$. 
eggs fertilized with the damaged sperm was conceived with a male pronucleus with DNA damage promoted by cryopreservation, because unfragmented spermatozoids were not detected. The reduction in fertilization rates for both cryopreservation procedures in relation to fresh sperm was related to the damage promoted during freezing-thawing that could compromise different spermatozoa functions (Silva \& Gadella 2006, Beirão et al. 2009). Nevertheless, fertilization rates were relatively high $(61.14 \% \pm$ and $66.73 \% \pm 2.10$ using egg yolk and LDL respectively) in relation to the apparently poor quality of the cryopreserved sperm. This fact could be associated with the high sperm:egg ratio applied in fertility trials $\left(1.6 \times 10^{7}\right.$ spermatozoa per egg). After fertilization, our results revealed a high number of abortions when both cryopreserved sperm were used. These abortions were related to the percentage of DNA damage detected after each cryopreservation procedure. Most of the abortions were produced in the transition from epibolia to somite stage, which entails a set of morphogenetic processes requiring bulk changes in gene expression with the transcription of a number of genes crucial for lineage specification (Solnica-Krezel 2006, Jaroudi \& SenGupta 2007, Tam \& Loebel 2007). This result reveals the capacity of DNA-damaged spermatozoa to fertilize, and points out their negative effect during early embryo development.

The ability of oocytes to repair DNA damage has been reported in different studies (Kopeika et al. 2004, Hales et al. 2005, Hakem 2008), but there are no references on the extent of damage that could be repaired during development. According to Ahmadi \& Ng (1999), mouse oocytes are able to repair up to $8 \%$ of sperm DNA fragmentation, but no experimental data support this hypothesis. It is considered that many strand breaks from the male pronucleus could be repaired during the first cleavage. DNA repair is achieved by different mechanisms, the activity of which has been detected during early embryo development (Matsuda \& Tobari 1989, Jaroudi \& SenGupta 2007, Marchetti et al. 2007, Hakem 2008). In our study, we detected simple and double strand breaks as well as oxidized bases. Repairing of DNA simple strand breaks and oxidized base replacement is performed by the BER pathway, a highly conserved mechanism based on the PARP which has also been described in fish (Fortier et al. 2009), whereas double strand breaks are repaired by the homologous recombination (HR) pathway or the nonhomologous end joining (NHEJ) pathway (Hakem 2008). When PARP was inhibited by $3 \mathrm{AB}$ during the first cleavage, $94.60 \%$ of the embryos fertilized with egg yolk-cryopreserved sperm died, showing that all fertilizing spermatozoa in these samples led to genetic damage requiring repair by the BER pathway of the oocyte. Without PARP inhibition, $76.34 \%$ of fertilized oocytes failed to hatch, indicating that a high percentage of fertilizing spermatozoids carry irreparable DNA damage and that the successful $20 \%$ hatched embryos were conceived with DNA damage reparable by the BER pathway. These data suggest that trout oocytes are able to repair at least $10 \%$ of sperm DNA fragmentation, because no spermatozoa with a lower level of fragmentation were detected in these samples. This finding is in the range of that suggested by Ahmadi \& Ng (1999) for mouse oocytes.

LDL-cryopreserved sperm promoted the abortion of $49.21 \%$ embryos showing the presence of unrepaired DNA damage. However, surprisingly, in contrast to embryos resulting from egg yolk-cryopreserved sperm, treatment with $3 \mathrm{AB}$ did not promote an increase in abortion. The basal percentage of abortions (in untreated $3 \mathrm{AB}$ embryos) could indicate fertilization with spermatozoa containing different genetic damage: simple or double strand breaks, base oxidization, packaging changes, or epigenetic modifications. The percentage of fertilizing spermatozoa carrying damage reparable by the BER pathway is not significant. This implies that the extent of double and simple strand breaks (non-distinguishable with this comet assay) could be different in fertile spermatozoids from samples frozen with egg yolk or with their LDL fraction. The use of different inhibitors of the repair system, during different stages of early development and fertilization with spermatozoa carrying different kinds of DNA damage, could help to characterize the repair process and to define the extent and type of damage that could be tolerated. Taking into account that repair DNA pathways such as BER, HR, or NHEJ are highly conserved mechanisms, fish could be very interesting models for this purpose. The high number of fertilized embryos that can be obtained and their external development - giving easy access to the embryo during development - are important advantages.

In conclusion, cryopreserved sperm from rainbow trout carrying damaged DNA are able to fertilize, affecting offspring survival. In addition, some degree of DNA fragmentation from the male pronucleus is repaired by the oocyte, and unrepaired damage promotes the abortion of the embryo. The presence of different kinds of damage such as simple or double strand breaks, base oxidization, or packaging modifications could imply developmental failures by different ways, and needs to be studied in depth. The numerous advantages of rainbow trout could help in understanding processes related to fertilization with DNA-damaged spermatozoa when processes of sperm selection are bypassed by ARTs in other species.

\section{Materials and Methods}

\section{Reagents}

All media components were purchased from Sigma-Aldrich or Merck unless another source is stated. 


\section{Animals}

Fresh sperm and eggs were obtained from four males and two females rainbow trout from the Las Zayas fish-farm stock (León, Spain). The fish were maintained under natural photoperiod, and gametes were obtained during the natural reproductive season. Sperm were collected by cannulation and abdominal massage, and motility was checked according to the method described by Robles et al. (2003). Modified sperm were diluted $1: 100$ in SFMM $(110 \mathrm{mM} \mathrm{NaCl}, 28.18 \mathrm{mM} \mathrm{KCl}, 1.22 \mathrm{mM}$ $\mathrm{MgSO}_{4} \times 7 \mathrm{H}_{2} \mathrm{O}, 1.77 \mathrm{mM} \mathrm{CaCl} \mathrm{C}_{2} \times 2 \mathrm{H}_{2} \mathrm{O}, 10.05 \mathrm{mM}$ bicine, and $9.99 \mathrm{mM}$ HEPES), an immobilizing solution, and then, $10 \mu \mathrm{l}$ of the sperm dilution were placed on a glass slide, and immediately, $100 \mu \mathrm{l}$ of DIA532 $(94.97 \mathrm{mM} \mathrm{NaCl}, 49.95 \mathrm{mM}$ glycine, and $19.98 \mathrm{mM}$ Tris) were added to activate motility. Only samples with more than $90 \%$ motile spermatozoa were used. Oocytes required for fertilization trials were extracted by stripping from females anesthetized with MS222. Eggs were pooled and divided into 200 egg batches for fertilization trials.

\section{Sperm cryopreservation}

Immediately after collection, sperm were frozen using the protocol described by Herráez et al. (2008). Sperm from each male were diluted 1:3 (sperm:extender) in \#6 from Erdahl and Graham $\left(0.7 \mathrm{mM} \mathrm{CaCl} \mathrm{C}_{2} \times 2 \mathrm{H}_{2} \mathrm{O}, 1.08 \mathrm{mM} \mathrm{MgCl}_{2} \times 6 \mathrm{H}_{2} \mathrm{O}\right.$, $1.49 \mathrm{mM} \mathrm{Na}_{2} \mathrm{HPO}_{4}, 34.30 \mathrm{mM} \mathrm{KCl}, 100 \mathrm{mM} \mathrm{NaCl}, 0.52 \mathrm{mM}$ citric acid, $55.5 \mathrm{mM}$ glucose, $226 \mathrm{mM} \mathrm{KOH}$ solution, $20 \mathrm{ml}$, $324 \mathrm{mM}$ bicine solution, $20 \mathrm{ml}$, and $323 \mathrm{mOsm} / \mathrm{kg}$, $\mathrm{pH}$ 7.4), containing $7 \% \mathrm{Me}_{2} \mathrm{SO}(\mathrm{v} / \mathrm{v})$ as a permeable cryoprotectant and $10 \%(\mathrm{v} / \mathrm{v})$ egg yolk or $12 \% \mathrm{LDL}(\mathrm{w} / \mathrm{v})$ as a membrane protector. LDL was obtained using the protocol described by Moussa et al. (2002). The sperm were then left to equilibrate for $10 \mathrm{~min}$ at $4{ }^{\circ} \mathrm{C}$ and loaded into French straws $(0.5 \mathrm{ml})$. The loaded straws were kept for $10 \mathrm{~min}$ in a floating device $2 \mathrm{~cm}$ above liquid nitrogen in a styrofoam box. They were then immersed in liquid nitrogen and stored in a liquid nitrogen tank until analysis. Thawing was carried out in a water bath at $25^{\circ} \mathrm{C}$ for $30 \mathrm{~s}$, and the sperm analyses and fertilization trials were performed immediately.

\section{Spermatozoa viability}

Spermatozoa viability was evaluated using the fluorescent 'live/dead Kit' (Molecular Probes, Leiden, The Netherlands), containing propidium iodide (PI) and SYBR-14 and the flow cytometer (FACSort Plus Analyzer, Becton-Dickinson, Franklin Lakes, NJ, USA) method validated for freshwater fish by Flajshans et al. (2004). Each sample was diluted to $1.6 \times 10^{7}$ cells $/ \mathrm{ml}$ in SFMM solution at a final volume of $1 \mathrm{ml}$. SYBR was added to a final concentration of $100 \mathrm{nM}$, and was incubated in the dark for $10 \mathrm{~min}$. Then, PI was added to a final concentration of $12 \mu \mathrm{M}$, and was kept in the dark for $10 \mathrm{~min}$. After this, flow cytometry analysis was performed for obtaining the percentages of red cells (cells with damaged membrane) and green cells (cells with intact membrane in this test).

\section{Analysis of ROS in the sperm}

For positive control of oxidization, one aliquot of each fresh sperm sample was 40 -fold diluted in SFMM containing $500 \mathrm{mM} \mathrm{H} \mathrm{O}_{2}$ for $20 \mathrm{~min}$ at $4{ }^{\circ} \mathrm{C}$. Fresh and frozen sperm aliquots were diluted to a final concentration of $2 \times 10^{6}$ in SFMM, and $5 \mu \mathrm{l}$ of $0.5 \mu \mathrm{M} \mathrm{H}_{2}$ DCFDA were added to each sample for the detection of intracellular ROS. The aliquots were then incubated at $4{ }^{\circ} \mathrm{C}$ in the dark for $5 \mathrm{~min}$, and analyzed by flow cytometry by the measurement of mean fluorescence emission for each sample. Results were reported in MFI as mean \pm S.E.M.

\section{Flow cytometer configuration}

The flow cytometer (FACSort Plus Analyzer, Becton-Dickinson) was equipped with standard optics and an argon ion laser (Innova 90, Coherent Inc., Santa Clara, CA, USA), with CellQuest software for Macintosh (version 3.0, BectonDickinson) for acquisition and analysis, and with FACSComp software (version 1.0) for daily setup and quality control. The red fluorescence emitted by PI was detected using a 610-nm filter, and the green fluorescence emitted by SYBR-14 and H2DCFDA was detected using a 516-nm filter. The evaluation was carried out in all samples and assays in triplicate, acquiring 10000 cells each time.

\section{Sperm DNA damage}

DNA fragmentation was analyzed using the SCGE or comet assay. Prior to the assay, one aliquot of fresh sperm from each male was treated with $\mathrm{H}_{2} \mathrm{O}_{2}$ by 40 -fold dilution in $500 \mathrm{mM}$ $\mathrm{H}_{2} \mathrm{O}_{2}$ in SFMM at $4{ }^{\circ} \mathrm{C}$ for 20 min to be used as DNAfragmented positive control. Fresh, cryopreserved, and $\mathrm{H}_{2} \mathrm{O}_{2}$ treated sperm were diluted in SFMM to a final concentration of $8-10 \times 10^{6} / \mathrm{ml}$. Frozen sperm were prepared immediately after thawing to prevent sperm degradation. Slides for sperm smears were prepared in advance as described by Cabrita et al. (2005). All buffers were prepared fresh. After spreading the sperm, the slides were immersed in a cold lysis solution $(2.5 \mathrm{M} \mathrm{NaCl}$, $100 \mathrm{mM} \mathrm{Na}{ }_{2}$ EDTA, $10 \mathrm{mM}$ Tris, 1\% Triton-X, 1\% lauroyl sarcosine sodium salt, and $4 \mathrm{mM}$ lithium diiodosalicylate, $\mathrm{pH}$ 8), and were incubated for $1 \mathrm{~h}$ at $4{ }^{\circ} \mathrm{C}$. After lysis, the slides were washed in an enzymatic buffer solution (40 mM HEPES, $0.1 \mathrm{M} \mathrm{KCl}, 0.5 \mathrm{mM}$ EDTA, and $0.2 \mathrm{mg} / \mathrm{ml} \mathrm{BSA}, \mathrm{pH}$ 8.0) three times for $5 \mathrm{~min}$, and were covered either with $40 \mu \mathrm{l}$ of buffer alone or with endonuclease $(1 \mu \mathrm{g} / \mathrm{ml}$ of EndIII) or $22 \mu \mathrm{g} / \mathrm{ml}$ of Fpg from Escherichia coli) and sealed with cover slips. Then, all the slides were incubated for $45 \mathrm{~min}$ at $37^{\circ} \mathrm{C}$ to activate the enzymatic reaction. Then, the slides were placed in an electrophoresis cube (Bio-Rad) containing an electrophoresis buffer (0.3 M NaOH and $1 \mathrm{mM} \mathrm{Na} \mathrm{m}_{2}$ EDTA, pH 12) for $20 \mathrm{~min}$ at $4{ }^{\circ} \mathrm{C}$. Electrophoresis was performed for $10 \mathrm{~min}$ at $25 \mathrm{~V}$ and $300 \mathrm{~mA}$ at $4{ }^{\circ} \mathrm{C}$. The slides were then neutralized with $0.4 \mathrm{M}$ Tris, $\mathrm{pH} 7.5$, for $5 \mathrm{~min}$ at $4{ }^{\circ} \mathrm{C}$. This operation was repeated three times to ensure the elimination of all alkali and detergents. The slides were fixed by immersion in a pure methanol solution for $3 \mathrm{~min}$, and were left to drain in air and stored protected from light and dust. 
For comet visualization, $40 \mu \mathrm{l}$ of ethidium bromide, $0.5 \mu \mathrm{g} / \mathrm{ml}$, were pipetted onto the slides, which were then covered with cover slips. Samples were observed using an epifluorescence microscope (Nikon Eclipse E800; Nikon, Lijnden, The Netherlands) fitted with a 510-560-nm excitation filter and a 590-nm barrier filter. Images were acquired from the microscope with a Nikon DXM1200F digital camera, acquiring $\sim 50$ cells from each slide using Nikon ACT-1 software (v. 2.62, Nikon). All the images were analyzed with the Komet imaging system software (version 5; Kinetic Imaging, Liverpool, UK). Two slides were analyzed per male and treatment. The percentage of tail DNA (fragmented DNA) was obtained for each treatment. Frequencies of cells for each degree of tail DNA were analyzed.

\section{Fertilization and egg DNA repair inhibition}

Eggs were fertilized with sperm from each male using fresh sperm diluted 1:3 (sperm:extender) in \#6 from Erdahl and Graham and cryopreserved sperm (2400 eggs per male: four batches of 200 eggs/treatment). One milliliter of sperm was directly spread over 200 eggs, and motility was activated with $10 \mathrm{ml}$ of DIA532 solution. Ten minutes later, the eggs were washed with water and incubated in the dark for $6 \mathrm{~h}$ at $4{ }^{\circ} \mathrm{C}$ (during the first cleavage) in $15 \mathrm{mM} 3 \mathrm{AB}$ (two batches per treatment) to inhibit the PARP activity or in water (the two other batches). The eggs were washed with water and incubated until hatching.

\section{Incubation and evaluation of development}

The fertilized eggs were maintained in the dark under controlled conditions $\left(10^{\circ} \mathrm{C}\right)$ until hatching. Thirty embryos from each batch were taken on days 5, 9, 16, and 26 to evaluate embryo survival at four developmental stages: epibolia, somite, eyed, and hatch.

To visualize embryo development in epibolia, somite, and eyed stages, the eggs were treated (cleared) with a solution containing acetic acid, methanol, and $\mathrm{H}_{2} \mathrm{O}(1: 1: 1)$.

\section{Statistical analysis}

Statistical analysis was carried out using the computerized package generated by SPSS 14.0 software for Windows (SPSS Inc., Chicago, IL, USA). The results were expressed as means \pm s.E.M. Mean values of the percentage of tail DNA were obtained from 400 cells (100 from each male); mean values of viability and ROS were obtained from $10^{4}$ cells from each sample; and mean values of fertilization rates, hatching rates, and abortions were obtained from 800 eggs (200 from each male sperm sample and post-fertilization treatment). Means of spermatozoa viability, percentage of tail DNA, ROS, fertilization rates, and hatching rates were compared and analyzed by one-way ANOVA $(P<0.05)$. Frequencies of tail DNA were compared for enzyme treatments by $\chi^{2}$ test $(P<0.05)$. Percentage of accumulative abortions was also analyzed using a linear mixed-effects model analysis $(P<0.05)$.

\section{Declaration of interest}

The authors declare that there is no conflict of interest that could be perceived as prejudicing the impartiality of the research reported.

\section{Funding}

This work was supported by grant LE007A06 from the Junta de Castilla y León (Spain).

\section{Acknowledgements}

S Pérez-Cerezales was supported by a PhD grant from the University of León. The authors thank Felipe Martínez-Pastor for the critical reading of the manuscript.

\section{References}

Ahmadi A \& Ng SC 1999 Fertilizing ability of DNA-damaged spermatozoa. Journal of Experimental Zoology 284 696-704.

Andrabi SM 2007 Mammalian sperm chromatin structure and assessment of DNA fragmentation. Journal of Assisted Reproduction and Genetics 24 561-569.

Barroso G, Valdespin C, Vega E, Kershenovich R, Avila R, Avendaño C \& Oehninger S 2009 Developmental sperm contributions: fertilization and beyond. Fertility and Sterility $92835-848$.

Baumber J, Ball BA, Linfor JJ \& Meyers SA 2003 Reactive oxygen species and cryopreservation promote DNA fragmentation in equine spermatozoa. Journal of Andrology 24 621-628.

Beirão J, Soares F, Herráez MP, Dinis MT \& Cabrita E 2009 Sperm quality evaluation in Solea senegalensis during the reproductive season at cellular level. Theriogenology 72 1251-1261.

Bowdin S, Allen C, Kirby G, Brueton L, Afnan M, Barratt C, Kirkman-Brown J, Harrison R, Maher ER \& Reardon W 2007 A survey of assisted reproductive technology births and imprinting disorders. Human Reproduction 22 3237-3240.

Box HC, Dawidzik JB \& Budzinski EE 2001 Free radical-induced double lesions in DNA. Free Radical Biology \& Medicine 31 856-868.

Cabrita E, Robles V, Rebordinos L, Sarasquete C \& Herraez MP 2005 Evaluation of DNA damage in rainbow trout (Oncorhynchus mykiss) and gilthead sea bream (Sparus aurata) cryopreserved sperm. Cryobiology $\mathbf{5 0}$ 144-153.

Cabrita E, Robles V \& Herráez MP 2008 Sperm quality assessment. In Methods in Reproductive Aquaculture. Marine and Freshwater Species, pp 93-147. Eds E Cabrita, V Robles \& MP Herráez. London: Taylor and Francis.

Cosson J, Groison AL, Suquet M, Fauvel C, Dreanno C \& Billard R 2008 Marine fish spermatozoa: racing ephemeral swimmers. Reproduction $136277-294$.

Dietrich GJ, Szpyrka A, Wojtczak M, Dobosz S, Goryczko K, Zakowski L \& Ciereszko A 2005 Effects of UV irradiation and hydrogen peroxide on DNA fragmentation, motility and fertilizing ability of rainbow trout (Oncorhynchus mykiss) spermatozoa. Theriogenology $\mathbf{6 4}$ 1809-1822.

Enciso M, Lopez-Fernandez C, Fernandez JL, Garcia P, Gosalbez A \& Gosalvez J 2006 A new method to analyze boar sperm DNA fragmentation under bright-field or fluorescence microscopy. Theriogenology 65 308-316.

Evenson DP \& Wixon R 2006 Clinical aspects of sperm DNA fragmentation detection and male infertility. Theriogenology 65 979-991.

Evenson DP, Jost LK, Baer RK, Turner TW \& Schrader SM 1991 Individuality of DNA denaturation patterns in human sperm as measured by the sperm chromatin structure assay. Reproductive Toxicology $\mathbf{5}$ 115-125. 
Fernandez-Gonzalez R, Moreira PN, Perez-Crespo M, Sanchez-Martin M, Ramirez MA, Pericuesta E, Bilbao A, Bermejo-Alvarez P, de Dios Hourcade J, de Fonseca FR et al. 2008 Long-term effects of mouse intracytoplasmic sperm injection with DNA-fragmented sperm on health and behavior of adult offspring. Biology of Reproduction 78 761-772.

Flajshans M, Cosson J, Rodina M \& Linhart O 2004 The application of image cytometry to viability assessment in dual fluorescence-stained fish spermatozoa. Cell Biology International 28 955-959.

Fortier S, Yang X, Wang Y, Bennett RA \& Strauss PR 2009 Base excision repair in early zebrafish development: evidence for DNA polymerase switching and standby AP endonuclease activity. Biochemistry 48 5396-5404.

Hakem R 2008 DNA-damage repair; the good, the bad, and the ugly. EMBO Journal 27 589-605.

Hales BF, Aguilar-Mahecha A \& Robaire B 2005 The stress response in gametes and embryos after paternal chemical exposures. Toxicology and Applied Pharmacology 207 514-520.

Herráez MP, Robles V \& Cabrita E 2008 Rainbow trout (Oncorhynchus mykiss) sperm cryopreservation. In Methods in Reproductive Aquaculture. Marine and Freshwater Species, pp 385-389. Eds E Cabrita, V Robles \& MP Herráez. London: Taylor and Francis.

Holt WV \& Van Look KJ 2004 Concepts in sperm heterogeneity, sperm selection and sperm competition as biological foundations for laboratory tests of semen quality. Reproduction 127 527-535.

Hourcade JD, Perez-Crespo M, Fernandez-Gonzalez R, Pintado B \& Gutierrez-Adan A 2010 Selection against spermatozoa with fragmented DNA after postovulatory mating depends on the type of damage. Reproductive Biology and Endocrinology 89.

Hu JH, Li QW, Jiang ZL \& Li WY 2008 Effects of different extenders on DNA integrity of boar spermatozoa following freezing-thawing. Cryobiology $57257-262$.

Irvine DS, Twigg JP, Gordon EL, Fulton N, Milne PA \& Aitken RJ 2000 DNA integrity in human spermatozoa: relationships with semen quality. Journal of Andrology 21 33-44.

Jalabert B 2005 Particularities of reproduction and oogenesis in teleost fish compared to mammals. Reproduction, Nutrition, Development $\mathbf{4 5}$ 261-279.

Jaroudi S \& SenGupta S 2007 DNA repair in mammalian embryos. Mutation Research 635 53-77.

Khalil AA, Petrunkina AM, Sahin E, Waberski D \& Topfer-Petersen E 2006 Enhanced binding of sperm with superior volume regulation to oviductal epithelium. Journal of Andrology 27 754-765.

Kopeika J, Kopeika E, Zhang T, Rawson DM \& Holt WV 2004 Effect of DNA repair inhibitor (3-aminobenzamide) on genetic stability of loach (Misgurnus fossilis) embryos derived from cryopreserved sperm. Theriogenology 61 1661-1673.

Lee RF \& Steinert S 2003 Use of the single cell gel electrophoresis/comet assay for detecting DNA damage in aquatic (marine and freshwater) animals. Mutation Research 544 43-64.

Li ZL, Lin QL, Liu RJ, Xie WY \& Xiao WF 2007 Reducing oxidative DNA damage by adding antioxidants in human semen samples undergoing cryopreservation procedure. Zhonghua Yi Xue Za Zhi 87 3174-3177.

Liao W, McNutt MA \& Zhu W 2009 The comet assay: a sensitive method for detecting DNA damage in individual cells. Methods $\mathbf{4 8}$ 46-53.

Lim D, Bowdin SC, Tee L, Kirby GA, Blair E, Fryer A, Lam W, Oley C, Cole T, Brueton LA et al. 2009 Clinical and molecular genetic features of Beckwith-Wiedemann syndrome associated with assisted reproductive technologies. Human Reproduction 24 741-747.

Maluszynska J \& Juchimiuk J 2005 Plant genotoxicity: a molecular cytogenetic approach in plant bioassays. Arhiv za Higijenu Rada $i$ Toksikologiju 56 177-184.

Marchetti F, Essers J, Kanaar R \& Wyrobek AJ 2007 Disruption of maternal DNA repair increases sperm-derived chromosomal aberrations. PNAS 104 17725-17729.
Matsuda Y \& Tobari I 1989 Repair capacity of fertilized mouse eggs for $X$-ray damage induced in sperm and mature oocytes. Mutation Research $21035-47$.

Moussa M, Marinet V, Trimeche A, Tainturier D \& Anton M 2002 Low density lipoproteins extracted from hen egg yolk by an easy method: cryoprotective effect on frozen-thawed bull semen. Theriogenology $\mathbf{5 7}$ 1695-1706.

Pérez-Cerezales S, Martínez-Páramo S, Cabrita E, Martínez-Pastor $F$, de Paz P \& Herráez MP 2009 Evaluation of oxidative DNA damage promoted by storage in sperm from sex-reversed rainbow trout. Theriogenology 71 605-613.

Pérez-Cerezales S, Martínez-Páramo S, Beirão J \& Herráez MP 2010 Evaluation of DNA damage as a quality marker for rainbow trout sperm cryopreservation an use of $\mathrm{LDL}$ as cryoprotectant. Theriogenology [in press]. DOI:10.1016/j.theriogenology.2010.02.012.

Robles V, Cabrita E, Cuñado S \& Herráez MP 2003 Sperm cryopreservation of sex-reversed rainbow trout (Oncorhynchus mykiss): parameters that affect its ability for freezing. Aquaculture 224 203-212.

Rodriguez-Martinez H 2007 Role of the oviduct in sperm capacitation. Theriogenology 68S S138-S146.

Satake N, Elliott RM, Watson PF \& Holt WV 2006 Sperm selection and competition in pigs may be mediated by the differential motility activation and suppression of sperm subpopulations within the oviduct. Journal of Experimental Biology 209 1560-1572.

Schulte RT, OhI DA, Sigman M \& Smith GD 2010 Sperm DNA damage in male infertility: etiologies, assays, and outcomes. Journal of Assisted Reproduction and Genetics 27 3-12.

Silva PF \& Gadella BM 2006 Detection of damage in mammalian sperm cells. Theriogenology 65 958-978.

Singh NP, McCoy MT, Tice RR \& Schneider EL 1988 A simple technique for quantitation of low levels of DNA damage in individual cells. Experimental Cell Research 175 184-191.

Solnica-Krezel L 2006 Gastrulation in zebrafish - all just about adhesion? Current Opinion in Genetics \& Development 16 433-441.

Suarez SS \& Pacey AA 2006 Sperm transport in the female reproductive tract. Human Reproduction Update 12 23-37.

Sun JG, Jurisicova A \& Casper RF 1997 Detection of deoxyribonucleic acid fragmentation in human sperm: correlation with fertilization in vitro. Biology of Reproduction 56 602-607.

Tam PP \& Loebel DA 2007 Gene function in mouse embryogenesis: get set for gastrulation. Nature Reviews. Genetics 8 368-381.

Tarin JJ, Perez-Albala S \& Cano A 2000 Consequences on offspring of abnormal function in ageing gametes. Human Reproduction Update 6 532-549.

Thomson LK, Fleming SD, Aitken RJ, De Iuliis GN, Zieschang JA \& Clark AM 2009 Cryopreservation-induced human sperm DNA damage is predominantly mediated by oxidative stress rather than apoptosis. Human Reproduction 24 2061-2070.

Yamauchi S, Nakamura S, Lay KM, Azuma T, Yakabi T, Muto N, Nakada T, Ashizawa K \& Tatemoto H 2009 Characteristics of okinawan native agu pig spermatozoa after addition of low-density lipoprotein to freezing extender. Journal of Reproduction and Development 55 558-565.

Yeates SE, Einum S, Fleming IA, Megens HJ, Stet RJ, Hindar K, Holt WV, Van Look KJ \& Gage MJ 2009 Atlantic salmon eggs favour sperm in competition that have similar major histocompatibility alleles. Proceedings of the Royal Society of London, Series B: Biological Sciences 276 559-566.

Zini A \& Sigman M 2009 Are tests of sperm DNA damage clinically useful? Pros and cons Journal of Andrology 30 219-229.

Received 19 January 2010

First decision 16 February 2010

Accepted 31 March 2010 